\title{
Virtues, skills, and the practice of surgery
}

\author{
David Schenck, PhD
}

From the Ethics Program, Medical University of South Carolina, Charleston, SC.

Disclosures: Author has nothing to disclose with regard to commercial support.

Received for publication Sept 26, 2016; revisions received Sept 26, 2016; accepted for publication Sept 26, 2016; available ahead of print Nov 12, 2016.

Address for reprints: David Schenck, PhD, Medical University of South Carolina, 169 Ashley Ave, Suite $260 \mathrm{MH}$, MSC 332, Charleston, SC 29425 (E-mail: schenck@musc.edu).

J Thorac Cardiovasc Surg 2017;153:1218-9

0022-5223/\$36.00

Copyright (c) 2016 by The American Association for Thoracic Surgery

http://dx.doi.org/10.1016/j.jtcvs.2016.09.072

Discussions of the virtues and virtue ethics in current bioethics literature are shaped by 2 primary concerns: (1) virtue ethics as a supplement to, if not a replacement for, the familiar "four principles" approach, ${ }^{1-4}$ enshrined in the Belmont report ${ }^{5}$ and championed by Childress and Beauchamp $^{6}$ in their classic textbook, Principles of Biomedical Ethics, and (2) continuing reflection on medicine as a practice - that is, as a set of habits shaped by apprenticeship and untold hours of skill development. ${ }^{7-10}$ Aristotle is quoted most often here, along with Alastair MacIntyre's dour diagnosis of contemporary moral life, After Virtue. ${ }^{11}$ Though it is less cited in recent years than is MacIntyre's book, Edmund Pelligrino's classic, The Virtues in Medical Practice, ${ }^{12}$ will remain through time a far richer resource for physicians.

Churchill's article ${ }^{13}$ in this issue of the Journal addresses both of these sets of concerns. Speaking to the first, concerns he draws on interviews with clinicians and patients to demonstrate that virtues are key parts of relationships between patients and clinicians. Virtues indeed are habits of relating, as he makes clear. ${ }^{14}$ Churchill $^{13}$ then turns to enumerate 8 virtues that he thinks are especially relevant to the practice of surgery. I will comment on his treatment of 2 of these, empathy and hope.

Empathy is most commonly assumed to be a matter of feelings, when its importance is even acknowledged. Churchill ${ }^{13}$ makes the excellent point that, to the contrary, empathy is better understood as a set of skills - as indeed all the virtues are. With such an approach, one could then argue that because the virtues, including empathy, are skills, they can be modeled, taught, and learned, like other clinical skills. There would be enormous implications for medical training if this insight were to be taken to heart.

The distinction between hope and optimism should be noted. Hope suggests a rootedness and tenacity that the more cerebral and intentional optimism does not. There is with hope a sense of determination and openness in approaching the future, which is particularly apt in the context of surgery.

Going further here, we can ask: What specific manifestation of hope by a surgeon qua surgeon might command our

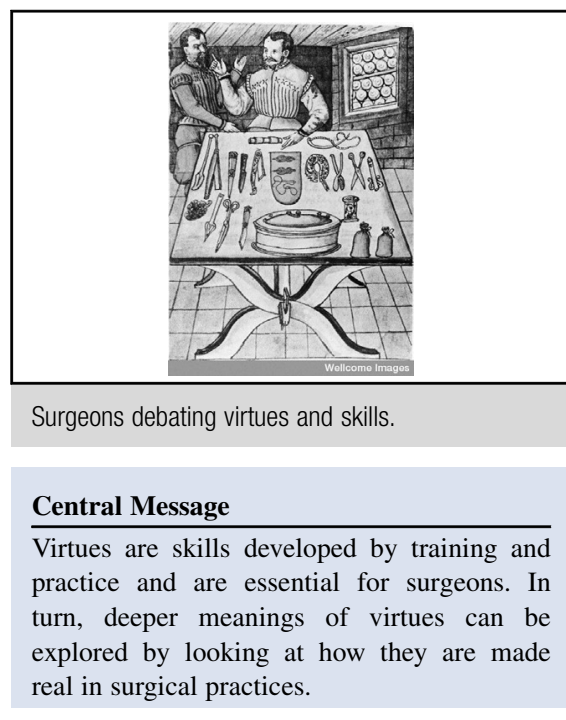

See Article page 1214.

attention? I would suggest the practice of seeking patient buy-in. Here the surgeon joins the patient in committing to a new life through and after the surgery, anticipating a complex process of recovery that will unfold over time. This I would argue is hope, fully realized. Nabozny and colleagues ${ }^{15}$ have written about surgical buy-in in ways that could help us to see it as an expression of hope that is distinctive to surgery.

More work might well be done with the other 7 virtues here, looking for the specific manifestations of these virtues within surgical practice itself. Such specificity is important if further discussion of virtues is not to devolve into platitudes. In particular, one might go further with what I think is the most striking phrase in Churchill's article ${ }^{13}$ : “All surgical interventions should be seen as essentially gestures of compassion." How could we spell this out? How can we make clear that incisions and sutures are gestures of compassion?

These brief remarks should serve to indicate that Churchill's insightful essay ${ }^{13}$ will be essential for future reflections on the virtues of surgeons and their surgical practice.

\section{References}

1. Karches KE. Justice, courage, and truthfulness: virtues that medical trainees can and must learn. Fam Med. 2016;48:511-6.

2. Misselbrook D. Virtue ethics - an old answer to a new dilemma? Part 1 . Problems with contemporary medical ethics. J R Soc Med. 2015;108: 53-6.

3. Misselbrook D. Virtue ethics — an old answer to a new dilemma? Part 2. The case for inclusive virtue ethics. J R Soc Med. 2015;108:89-92. 
4. Oakley J. Good medical ethics, from the inside out-and back again. J Med Ethics. 2015;41:48-51.

5. U.S. Department of Health \& Human Services. The Belmont Report. Available at: http://www.hhs.gov/ohrp/regulations-and-policy/belmont-report/. Accessed September 10, 2016.

6. Beauchamp TL, Childress JF. Principles of biomedical ethics. 7th ed. Oxford, UK: Oxford University Press; 2012.

7. Sade RM. The ethics of surgery: conflicts and controversies. Oxford, UK: Oxford University Press; 2015.

8. Vercler CJ. Surgical ethics: surgical virtue and more. Narrat Inq Bioeth. 2015;5: 45-51.

9. Larkin GL, McKay MP, Angelos P. Six core competencies and seven deadly sins: a virtues-based approach to new guidelines for graduate medical education. Surgery. 2005; 138:490-7.
10. Osler W. Aequanimitas (1925). Available at: http://www.medicalarchives.jhmi edu/osler/aequessay.htm. Accessed September 10, 2016.

11. MacIntyre A. After virtue. 3rd ed. Notre Dame (IN): University of Notre Dame Press; 2007

12. Pelligrino ED, Thomasma DC. The virtues in medical practice. Oxford, UK: Oxford University Press; 1993.

13. Churchill LR. The American Association for Thoracic Surgery 2016 ethics forum: working virtues in surgical practice. J Thorac Cardiovasc Surg. 2017;153:1214-7.

14. Andre J. Worldly virtue: moral ideals and contemporary life. Lanham (MD): Lexington Books; 2015.

15. Nabozny MJ, Kruser JM, Steffens NM, Pecanac KE, Brasel KJ, Chittenden EH, et al. Patient-reported limitations to surgical buy-in: a qualitative study of patients facing high-risk surgery. Ann Surg. January 18, 2016 [Epub ahead of print].

\section{Notice of Correction}

Re: Patel ND, Crawford T, Magruder T, Alejo DE, Hibino N, Black J, et al. Cardiovascular operations for Loeys-Dietz syndrome: Intermediate-term results. J Thorac Cardiovasc Surg. 2017;153:406-12.

In the above-mentioned article, Dr Black's name was incorrect. The author's name should read James H. Black III, MD. The corrected author list is reprinted below.

Nishant D. Patel, MD, Todd Crawford, MD, J. Trent Magruder, MD, Diane E. Alejo, BA, Narutoshi Hibino, MD, James H. Black III, MD, Harry C. Dietz, MD, Luca A. Vricella, MD, and Duke E. Cameron, MD 